\title{
The Methylation of Transfer and Ribosomal Ribonucleic Acid in Human Fibroblasts: Normal Methylation of Ribonucleic Acid in Cystic Fibrosis
}

\author{
Mrahael Klagsbrun and Philip M. Farrell ${ }^{[27]}$
}

Laboratory of Biochemical Pharmacology and the Pediatric Metabolism Branch, National Institute of Arthritis, Metabolism, and Digestive Diseases, National Institutes of Health, Bethesda, Maryland, USA

\section{Extract}

A comprehensive study of tRNA and $18 \mathrm{~S}$ and $28 \mathrm{~S}$ rRNA methylation in human fibroblasts is presented. Cells from normal volunteers and patients with cystic fibrosis (CF) were examined during exponential growth by incubation with $\mathrm{L}-\left(\right.$ methyl $\left.-{ }^{14} \mathrm{C}\right)$ methionine and $\left({ }^{3} \mathrm{H}\right)$ uridine. The ratio of ${ }^{14} \mathrm{C}$ to ${ }^{3} \mathrm{H}$ counts per minute in isolated RNA serves as a measure of the extent of methylation and was found to be similar in normal and CF fibroblasts for tRNA, $18 \mathrm{~S}$ rRNA, and $28 \mathrm{~S}$ rRNA. Hydrolyzed samples of $\left({ }^{14} \mathrm{C}\right)$ methyl-labeled RNA species were analyzed by two dimensional chromatography and autoradiography. The methylated base and nucleoside compositions of tRNA and rRNA agree well with data for HeLa cells and other eurkaryote cells such as those from yeast, mouse, and chicken. RNA methylation patterns in CF fibroblasts were qualitatively and quantitatively similar to those observed in normal cells for $4 \mathrm{~S}, 18 \mathrm{~S}$, and 28 S RNA. There is no evidence that RNA species from patients with cystic fibrosis are deficient in any methylated components.

\section{Speculation}

Methylation of RNA by tissue-cultured cells from cystic fibrosis patients is qualitatively and quantitatively normal and will not prove to be useful as a marker for identification of carriers of cystic fibrosis.

\section{Introduction}

Rennert et al. [13, 14] have reported that tissue-cultured fibroblasts and lymphocytes from patients with CF as well as obligatory heterozygotes for CF show a decreased methylation of RNA. If undermethylation of CF cells could be consistently demonstrated, a valuable and easily measurable marker for the detection of CF carriers would be available.

Therefore, a comprehensive study was undertaken of tRNA and $18 \mathrm{~S}$ and $28 \mathrm{~S}$ rRNA methylation in human fibroblasts by methods established previously in normal cells from various nonhuman organisms [6-8]. Accordingly, fibroblasts were isolated from normal volunteers and patients with $\mathrm{CF}$, and methylation of RNA was examined both in vivo, i.e., in tissue culture, and in vitro with fibroblast extracts. The results on methylation of tRNA in vitro and preliminary data on the methylation of tRNA in vivo are summarized briefly elsewhere [9]. Those findings indicated that all tRNA methylating enzymes that are present in normal human cells are also active in CF fibroblasts. In the present report, comprehensive data are 
presented on the in vivo methylation of tRNA and rRNA for fibroblasts from normal volunteers and CF patients.

\section{Materials and Methods}

\section{Cell Cultures and Media}

Skin biopsies were obtained from normal volunteers and from several patients with cystic fibrosis. The normal group (age range 21-23 years) included one pure blooded Chinese subject $(P J)$ who was almost certainly not a carrier for cystic fibrosis [16]. A broad spectrum with respect to age (10-24 years) and severity of disease was represented by the cystic fibrosis patients. Derived fibroblasts were cultured in $75 \mathrm{~cm}^{2}$ flasks containing Eagle's minimal essential medium plus a mixture of nonessential amino acids, $10 \%$ fetal calf serum, and neomycin sulfate $(50 \mu \mathrm{g} / \mathrm{ml})$. Both normal and $\mathrm{CF}$ cell lines had been serially subcultured seven to nine times before determination of RNA methylation. Cultures remained mycoplasma free as demonstrated by routine screening of the cell sheets and the media [17]. The mean generation time of fibroblasts in this laboratory based on cell counts is essentially the same for cystic fibrosis $(26 \pm 6 \mathrm{hr})$ and control $(27 \pm 9 \mathrm{hr})$ cells [11].

\section{Radioactive Methylation of $R N A$}

When the monolayers reached $25 \%$ confluence (i.e., during the exponential growth phase), RNA was labeled with $\mathrm{L}$-(methyl- $\left.{ }^{14} \mathrm{C}\right)$ methionine and $\left({ }^{3} \mathrm{H}\right)$ uridine. To accomplish this, the above growth medium was replaced by $12.5 \mathrm{ml}$ labeling medium for approximately $24 \mathrm{hr}$. The latter was identical with growth medium except for the lack of unlabeled methionine and the presence of $(1)$ L-(methyl-14 C) methionine $(0.25 \mu \mathrm{Ci} / \mathrm{ml}$, $50 \mathrm{mCi} / \mathrm{mmol}[18]) ;(2)\left({ }^{3} \mathrm{H}\right)$ uridine $(0.5 \mu \mathrm{Ci} / \mathrm{ml}, 27.7$ $\mathrm{Ci} / \mathrm{mmol}[19])$; (3) uridine $\left(5 \times 10^{-6} \mathrm{M}\right)$, and (4) adenosine $\left(10^{-4} \mathrm{M}\right)$. Uptake of isotopic precursors was found to be similar in a limited number of control and cystic fibrosis lines examined.

\section{Isolation of RNA}

Fibroblasts were removed from tissue culture flasks by trypsinization. The cells were harvested by centrifugation at $4,000 \times g$ for $5 \mathrm{~min}$, washed twice with Earle's basic salts, resuspended in $3 \mathrm{ml}$ RSB medium (0.01 M Tris, pH 7.5, $0.01 \mathrm{M} \mathrm{NaCl}$, and 0.0015 $\mathrm{M} \mathrm{MgCl}_{2}$ ) for $15 \mathrm{~min}$ to allow swelling, and then broken by 10 strokes in a tight-fitting Dounce homogenizer. Nuclei and large particulate matter were removed by two successive centrifugations of $1,000 \times g$ for $5 \mathrm{~min}$ and 10,000 $\times g$ for $15 \mathrm{~min}$. The supernatant fraction was extracted twice with an equal volume of $88 \%$ phenol at $60^{\circ}$ for 3 min, after addition of sodium dodecyl sulfate (SDS), to a final concentration of $0.25 \%$. The RNA was then precipitated from the aqueous phase by adding 2.5 volumes ethanol which contained $0.1 \mathrm{~m}$ sodium acetate buffer, pH 5.1, and allowing to stand at $-20^{\circ}$ overnight. The precipitate was washed twice with $70 \%$ ethanol, resuspended in $\mathrm{H}_{2} \mathrm{O}$, and kept frozen at $-20^{\circ}$.

Samples of tRNA and rRNA were prepared by centrifugation of the total cellular RNA on a $15 \%$ to $30 \%$ linear sucrose gradient made up in SDS buffer $(0.1 \mathrm{M}$ $\mathrm{NaCl}, 0.01 \mathrm{M}$ Tris, $\mathrm{pH}$ 7.5, 0.001 M ethylenediaminetetraacetate, and $0.5 \% \mathrm{SDS}$ ) at $20^{\circ}$ for $17 \mathrm{hr}$ at 27,000 $\mathrm{rpm}$ in the SW 41 rotor of the Spinco ultracentrifuge [1]. The distribution of RNA species was determined by continuous monitoring at $260 \mathrm{~nm}$ of the optical density of the sucrose gradient during collection. Tubes containing $4 \mathrm{~S}, 18 \mathrm{~S}$, and $28 \mathrm{~S}$ RNA were pooled, and the RNA was precipitated with 2.5 volumes ethanol. The pooled RNA was redissolved in water, and the radioactivity in each sample was determined by the method of Furano [3]. The samples were counted in a scintillation counter [20] with approximate efficiencies of $17 \%$ for ${ }^{3} \mathrm{H}$ and $40 \%$ for ${ }^{14} \mathrm{C}$; the crossover of ${ }^{14} \mathrm{C}$ into the low energy channel was about $10 \%$.

All RNA fractions isolated from the sucrose gradient were incubated with pancreatic deoxyribonuclease $(20$ $\mu \mathrm{g} / \mathrm{ml}$ ) in $0.002 \mathrm{M} \mathrm{MgCl}_{2}$ for $30 \mathrm{~min}$ at $37^{\circ}$. These fractions were then incubated in $0.1 \mathrm{M}$ Tris acetate, $\mathrm{pH} 8.6$, for 30 min at $37^{\circ}$. Because only $28 \mathrm{~S}, 18 \mathrm{~S}$, and $4 \mathrm{~S}$ RNA are methylated, all the methyl radioactivity in the $4 \mathrm{~S}$ region was considered to be tRNA [2].

As presented elsewhere [9], examination of the sucrose density gradients reveals similar profiles for ultraviolet absorbance and labeling with $\left({ }^{3} \mathrm{H}\right)$ uridine. Specific activities of RNA preparations were as reported previously [9]. (Approximately $80 \%$ of the total RNA is rRNA and 20\% is tRNA.) Thus, it is evident in these experiments that $\left({ }^{3} \mathrm{H}\right)$ uridine provides a uniform label for RNA. On the other hand, about $40 \%$ of the $\mathrm{L}$-(methyl-14 $\mathrm{C})$ methionine incorporation is found in rRNA and $60 \%$ is found in tRNA.

\section{Two Dimensional Chromatography of Methylated Bases}

Samples of $\left({ }^{14} \mathrm{C}\right)$ tRNA were lyophilized and resuspended in $1 \mathrm{ml}$ trifluoroacetic acid [2I]. The samples 
were sealed in evacuated Carius combustion tubes and heated to $170^{\circ}$ for $30 \mathrm{~min}$ in a Carius bomb [12]. After cooling, the tubes were opened and the trifluoroacetic acid removed by evaporation with a current of air. The dry residues were resuspended in $10 \mu \mathrm{H}_{2} \mathrm{O}$ and spotted on cellulose thin layer sheets with fluorescent indicator [22]. The sheets were chromatographed in the first direction in methanol-hydrochloric acid-water (70/20/ $10)$ and in the second direction in 1-butanol-acetic acidwater $(4 / 1 / 1)$. Thin layer sheets were autoradiographed with Kodak RB-54 medical x-ray film [23]. For quantitation, radioactive spots were located by autoradiography, scraped, and counted in toluene which contained 2,5-diphenyloxazole and 1,4-bis[2-(5-phenyloxazolyl)]benzene. The compounds were identified by cochromatography with methylated compounds purchased from Cyclo Chemical [24].

\section{Results}

\section{Extent of Methylation of $T R N A$ and $r R N A$}

Exponentially growing human fibroblasts isolated from four normal volunteers and six patients with cystic fibrosis were labeled for 24 hr with $\mathrm{L}$-(methyl- ${ }^{14} \mathrm{C}$ )methionine and $\left({ }^{3} \mathrm{H}\right)$ uridine. Analysis of the incorporation of $\mathrm{L}$-(methyl- $\left.{ }^{14} \mathrm{C}\right)$ methionine and $\left({ }^{3} \mathrm{H}\right)$ uridine into RNA indicates that both cystic fibrosis and normal human fibroblasts incorporate either isotope into RNA equally well. Thus, approximately the same number of ${ }^{3} \mathrm{H}$ or ${ }^{14} \mathrm{C}$ counts per minute are found in each sample of total RNA.

The ratio of ${ }^{14} \mathrm{C}$ to ${ }^{3} \mathrm{H}$ counts per minute in tRNA, $18 \mathrm{~S}$ ribosomal RNA, and $28 \mathrm{~S}$ ribosomal RNA is a measure of the extent of methylation of each of these RNA species. As is shown in Table $\mathrm{I}$, the mean values

Table I. The extent of methylation of $4 \mathrm{~S}, 18 \mathrm{~S}$, and $28 \mathrm{~S}$ RNA in human fibroblasts

\begin{tabular}{|c|c|c|c|}
\hline & \multicolumn{3}{|c|}{ Ratio of ${ }^{14} \mathrm{C}$ to ${ }^{3} \mathrm{H} \mathrm{cpm}$} \\
\hline & 4 S RNA & $18 \mathrm{~S}$ RNA & $28 \mathrm{~S} \mathrm{RNA}$ \\
\hline \multicolumn{4}{|l|}{ Normal } \\
\hline$B H$ & 0.322 & 0.107 & 0.075 \\
\hline$D L$ & 0.526 & C. 217 & 0.072 \\
\hline$H S$ & 0.400 & 0.116 & 0.070 \\
\hline HS (experiment 2) & 0.485 & 0.113 & 0.078 \\
\hline Mean & 0.433 & 0.138 & 0.073 \\
\hline \multicolumn{4}{|l|}{ Cystic fibrosis } \\
\hline$P G$ & 0.526 & 0.111 & 0.066 \\
\hline$A O$ & 0.434 & 0.117 & 0.069 \\
\hline$R M$ & 0.416 & 0.125 & 0.068 \\
\hline$R M$ (experiment 2) & 0.540 & 0.145 & 0.092 \\
\hline Mean & 0.479 & 0.124 & 0.073 \\
\hline
\end{tabular}

for ${ }^{14} \mathrm{C}$ to ${ }^{3} \mathrm{H}$ ratio of each of the RNA species in four samples of normal human cells are similar within experimental error to the ratios of each corresponding RNA species in four samples of cystic fibrosis cells. Thus, the extent of methylation of RNA in vivo is similar for cystic fibrosis and normal human fibroblasts.

\section{Base Composition of $t R N A$ Methylated in Vivo}

Despite the normal extent of methylation observed in the RNA of cystic fibrosis fibroblasts, it is possible that an altered distribution of methylated bases exists in the RNA of these cells. Samples of ( $\left.{ }^{14} \mathrm{C}\right)$-methyl-1abeled tRNA were hydrolyzed in trifluoroacetic acid and analyzed by two dimensional chromatography on thin layer cellulose sheets, which were then subsequently autoradiographed. Autoradiograms of the methylated bases and nucleosides of tRNA isolated from one normal human line $(D L)$ and from one cystic fibrosis line $(A O)$ are shown in Figure 1. The identities and the relative amounts of the methylated compounds found in the tRNA of four normal human lines and six cystic fibrosis lines are shown in Table II. In addition, repeat data for one normal $(H S)$ and one cystic fibrosis $(R M)$ sample, are given as evidence of reproducibility. It is apparent from Figure 1 and Table II that the patterns for the methylation of tRNA in vivo are qualitatively and quantitatively similar in normal human lines and cystic fibrosis lines. There are no extra or missing bases in either cell type. Thus, there is no evidence that tRNA samples from patients with cystic fibrosis are deficient in any of the methylated bases or nucleosides.

\section{Base Composition of rRNA Methylated in Vivo}

The $18 \mathrm{~S}$ and $28 \mathrm{~S}$ RNA methylation patterns were examined in two normal and two cystic fibrosis lines. (The relatively small amount of methylation that occurs in rRNA compared with tRNA [8] makes the processing of large numbers of samples difficult.) Autoradiograms of the methylated bases and nucleosides of $18 \mathrm{~S}$ and $28 \mathrm{~S}$ rRNA isolated from one normal human line $(B H)$ and one cystic fibrosis line $(A O)$ are shown in Figure 2. The identities and the relative amounts of the methylated compounds found in the $18 \mathrm{~S}$ and $28 \mathrm{~S}$ rRNA of two normal lines and two cystic fibrosis lines are presented in Table III. As is the case with the methylation of tRNA in vivo, the patterns for the methylation of each of the ribosomal RNA species in vivo are qualitatively and quantitatively similar in normal human lines and cystic fibrosis lines. In addition, the data shown in Tables II and III for the methylation of tRNA and rRNA in vivo in human fibro- 


\section{Normal}

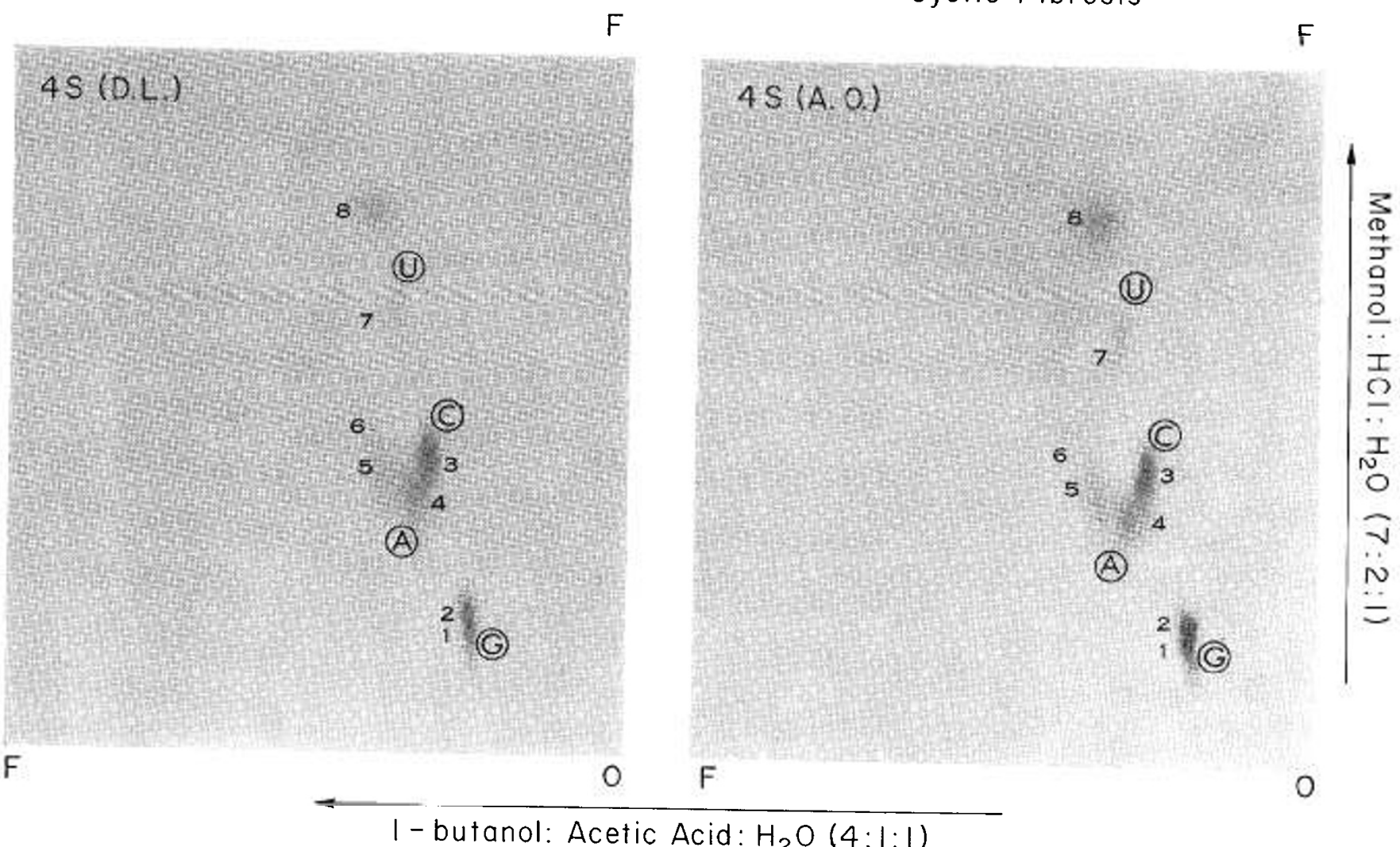

Fig. 1. Autoradiography of the methylated bases and nucleosides of tRNA. Samples of tRNA isolated from normal $(D L)$ and cystic fibrosis $(A O)$ fibroblasts as described in Materials and Methods were hydrolyzed in trifluoroacetic acid and chromatogra shed in two dimensions on cellulose thin layer sheets which were then autoradiographed. Guanine $(G)$, adenine $(A)$, cytosine $(C)$, and uridine $(U)$ markers were added and and quantitated in Table II with use of the same identification numbers published previously [8]. The total ${ }^{14} \mathrm{C}$ activities recovered by scraping the thin layer sheets were $566 \mathrm{cpm}$ in the normal sample $(D L)$ and $699 \mathrm{cpm}$ in the cystic fibrosis sample $(A O)$.

Table II. Relative amounts of methylated compounds recovered from $4 \mathrm{~S}$ RNA

\begin{tabular}{|c|c|c|c|c|c|c|c|c|c|c|c|c|c|c|c|c|}
\hline \multirow{3}{*}{$\begin{array}{l}\text { Identification } \\
\text { No.1 }\end{array}$} & \multirow{3}{*}{ Compound } & \multicolumn{15}{|c|}{ Total radioactivity recovered, $\%$} \\
\hline & & \multicolumn{7}{|c|}{ Normal } & \multicolumn{8}{|c|}{ Cystic fibrosis } \\
\hline & & $P J$ & $B H$ & $D L$ & $H S$ & $H S^{2}$ & Mear & $\mathrm{n} \pm \mathrm{SD}$ & $G F$ & $J S$ & HO & $P G$ & $A O$ & $R M$ & $R M^{2}$ & Mean $\pm \mathrm{sD}$ \\
\hline 1 & $\begin{array}{c}\text { 1-Methylguanine } \\
+\end{array}$ & & & & & & & & & & & & & & & \\
\hline 2 & 7-Methylguanine & 19.7 & 20.8 & 21.5 & 20.8 & 20.5 & 20.6 & \pm 0.65 & 19.9 & 19.7 & 19.5 & 23.3 & 23.7 & 20.2 & 21.0 & $21.0 \pm 1.7$ \\
\hline 3 & 1-Methyladenine & 17.2 & 18.0 & 17.9 & 16.0 & 18.6 & 17.5 & \pm 0.99 & 16.8 & 19.4 & 19.1 & 17.9 & 17.0 & 17.3 & 17.6 & $17.9 \pm 1.0$ \\
\hline 4 & $\mathrm{~N}^{2}$-Methylguanine & 16.7 & 17.3 & 17.0 & 15.6 & 17.0 & 16.7 & \pm 0.66 & 16.2 & 19.4 & 17.8 & 17.4 & 16.8 & 15.3 & 15.9 & $16.9 \pm 1.5$ \\
\hline 5 & $\mathrm{~N}^{2}$-Dimethylguanine & 15.1 & 14.8 & 13.9 & 14.3 & 14.4 & 14.5 & \pm 0.46 & 16.0 & 15.7 & 14.4 & 13.1 & 13.5 & 15.1 & 15.0 & $14.6 \pm 1.1$ \\
\hline 6 & 1-Methylhypoxanthine & 3.0 & 3.7 & 3.2 & 3.4 & 2.7 & 3.2 & \pm 0.38 & 3.1 & 2.3 & 2.5 & 2.5 & 2.5 & 2.7 & 3.6 & $2.7 \pm 0.46$ \\
\hline 7 & 5-Methylcytosine & 6.3 & 5.9 & 7.9 & 6.8 & 6.4 & 6.7 & \pm 0.77 & 6.3 & 6.0 & 5.1 & 6.4 & 8.4 & 7.2 & 8.7 & $6.9 \pm 1.2$ \\
\hline 8 & 5-Methyluridine & 21.9 & 19.0 & 18.4 & 22.7 & 20.5 & 20.5 & \pm 1.8 & 22.0 & 17.4 & 21.2 & 19.1 & 17.7 & 22.0 & 17.8 & $19.6 \pm 2.1$ \\
\hline
\end{tabular}

${ }^{1}$ Corresponds to numbers in Figure 1 as well as to numbers used previously [8].

blasts agree well with data reported previously for HeLa cells and other eukaryote cells [8].

\section{Discussion}

Various nucleic acids such as DNA, tRNA, and rRNA are found to be methylated in animal cells [2]. Methyla- tion is accomplished at the polynucleotide level with $S$-adenosylmethionine serving as the methyl donor. This process is catalyzed by a group of enzymes known as methylases which are highly specific with respect to individual bases and type of nucleic acid. Although the biologic role of nucleic acid methylation is as yet un- 


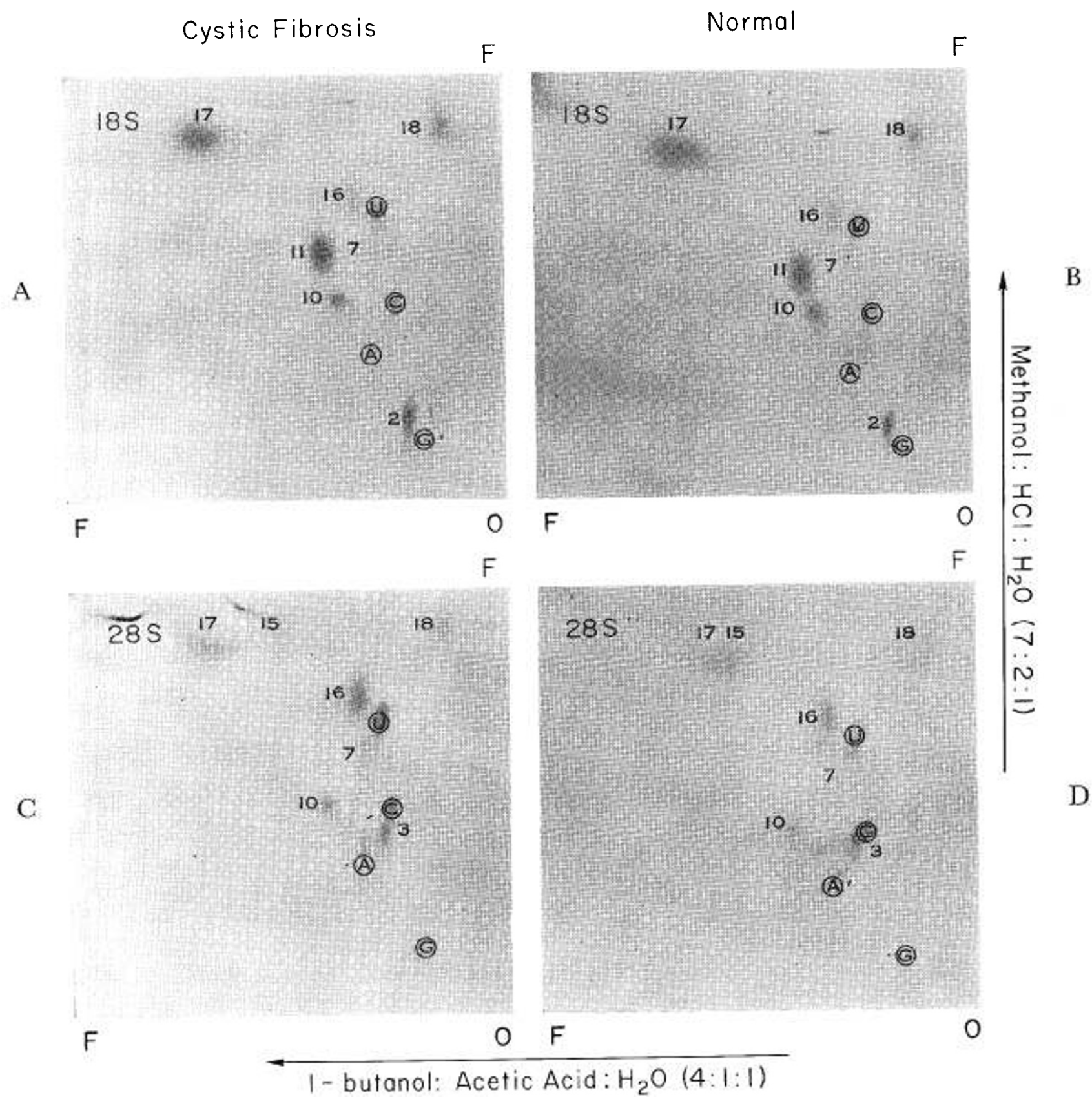

Fig. 2. Autoradiography of the methylated bases and nucleosides of $18 \mathrm{~S}$ and $28 \mathrm{~S}$ ribosomal RNA. Samples of $18 \mathrm{~S}$ and $28 \mathrm{~S}$ RNA isolated from normal $(B H)$ and cystic fibrosis $(A O)$ fibroblasts as described in Materials and Methods were hydrolyzed in trifluoroacetic acid and chromatographed in two dimensions on cellulose thin layer sheets which were then autoradiographed. Guanine $(G)$, adenine $(A)$, cytosine $(C)$, and uridine $(U)$ markers were added to $18 \mathrm{~S}$ and $28 \mathrm{~S}$ samples before hydrolysis and located on the chromatogram by ultraviolet absorption. The methylated compounds are identified and quantitated in Table III with the use of the same identification numbers previously pubtion. The methylated compounds are identified and quantitated in layer sheets were $272 \mathrm{cpm}$ for $18 \mathrm{~S}$ RNA and $94 \mathrm{cpm}$ for $28 \mathrm{~S}$ RNA in the normal sample $(B H)$, and $322 \mathrm{cpm}$ for 18 S RNA and $219 \mathrm{cpm}$ for $28 \mathrm{~S}$ RNA in the cystic fibrosis sample $(A O)$. The small amount of radionormal sample $(B H)$, and $322 \mathrm{cpm}$ for $18 \mathrm{~S}$ RNA $(D)$ makes the spots in the print of the autoradiogram difficult to discern; the original x-ray film, however, is quite clear. $A$ : cystic fibrosis $18 \mathrm{~S}$ RNA $(A O)$; $C$ : cystic fibrosis $28 \mathrm{~S}$ RNA $(A O)$; $B$ : normal $18 \mathrm{~S}$ RNA $(B H)$; $D:$ normal 28 S RNA $(B H)$. 
Table III. Relative amounts of methylated compounds recovered from $18 \mathrm{~S}$ and $28 \mathrm{~S}$ RNA

\begin{tabular}{|c|c|c|c|c|c|c|c|c|c|c|c|}
\hline \multirow{3}{*}{$\begin{array}{c}\text { Identification } \\
\text { No. }\end{array}$} & \multirow{3}{*}{ Compound ${ }^{2}$} & \multicolumn{10}{|c|}{ Total radioactivity recovered, $\%$} \\
\hline & & \multicolumn{5}{|c|}{$18 \mathrm{~S} \mathrm{RNA}$} & \multicolumn{5}{|c|}{$28 \mathrm{~S} \mathrm{RNA}$} \\
\hline & & $\begin{array}{c}\text { Cystic } \\
(A O) \\
\end{array}$ & $\begin{array}{l}\text { Cystic } \\
(R M)\end{array}$ & $\underset{(B H)}{\text { Normal }}$ & $\begin{array}{c}\text { Normal } \\
(D L)\end{array}$ & $\mathrm{HeLa}^{3}$ & $\begin{array}{l}\text { Cystic } \\
(A O)\end{array}$ & $\begin{array}{l}\text { Cystic } \\
(R D)\end{array}$ & $\underset{(B H)}{\text { Normal }}$ & $\begin{array}{c}\text { Normal } \\
(D L)\end{array}$ & $\mathrm{HeL}^{3}$ \\
\hline 2 & 7-Methylguanine & 6.0 & 9.0 & 8.5 & 5.7 & 7.2 & & & & & 2.3 \\
\hline 3 & 1-Methyladenine & & & & & 1.4 & 9.5 & 13.2 & 9.2 & 11.0 & 11.1 \\
\hline 7 & 5-Methylcy tosine & 2.2 & 3.5 & 4.5 & 3.3 & 2.8 & 5.3 & 4.7 & 5.2 & 6.9 & 3.4 \\
\hline 10 & $\mathrm{~N}^{6}$-Methyladenine & 8.5 & 7.7 & 9.2 & 6.0 & 8.2 & 7.6 & 7.3 & 8.0 & 8.2 & 10.5 \\
\hline 11 & $\mathrm{~N}^{6}$-Dimethyladenine & 22.7 & 21.5 & 18.0 & 19.8 & 23.9 & & & & & 2.4 \\
\hline 15 & 3-Methyluridine & & & & & & 11.6 & 8.5 & 8.6 & 12.0 & 6.8 \\
\hline 16 & 2-O-Methyluridine & 9.2 & 10.1 & 7.9 & 9.1 & 5.6 & 22.1 & 23.3 & 29.2 & 21.0 & 19.4 \\
\hline 17 & 2-O-Methylribose & 35.8 & 35.9 & 34.9 & 42.1 & 38.6 & 29.1 & 27.0 & 28.4 & 30.6 & 30.6 \\
\hline 18 & Unidentified & 15.6 & 11.9 & 14.2 & 13.7 & 10.7 & 14.7 & 16.4 & 10.9 & 10.8 & 11.1 \\
\hline
\end{tabular}

${ }^{1}$ Corresponds to numbers in Figure 2 as well as to numbers used previously [8].

${ }^{2}$ Tentative identification based on chromatographic data for HeLa, mouse, and yeast ribosomal RNA previously published [8].

${ }^{3}$ From data of Klagsbrun [8].

clear, it is possible that methylation of nucleic acids confers some protection against degradation by deoxyribonucleases and ribonucleases [4, 15].

It has been reported by Rennert et al. [13, 14] that a defect in the methylation of RNA is a characteristic of cells isolated from cystic fibrosis patients as well as obligatory heterozygotes. Thus, measurement of RNA methylation might be used as a test for cystic fibrosis carriers. In light of the importance that such a test could have in identification of cystic fibrosis heterozygotes, a comprehensive study of the tRNA and rRNA methylation has been performed with cultured fibroblasts isolated from six CF patients.

The results presented herein fail to demonstrate any significant differences in the methylation of RNA in CF fibroblast lines as compared with human fibroblasts isolated in an identical manner from four normal volunteers. Specifically, it was found that fibroblasts from $C F$ patients were normal with respect to: $(l)$ the extent of methylation in vivo of tRNA, $18 \mathrm{~S} \mathrm{RNA}$, and 28 S RNA, and (2) the methylated base composition of tRNA and rRNA methylated in vivo.

Additionally, it has previously been observed by Klagsbrun and Farrell [9] that cytoplasmic extracts from cystic fibrosis fibroblasts have the same capacity for methylation of $E$. coli tRNA in vitro as do extracts from normal human fibroblasts. Furthermore, the distribution of tRNA methylating enzymes observed in normal fibroblasts was the same in CF extracts [9], and thus an absent methylase could not be detected in the latter cells. Therefore, the in vivo methylation data of this report combined with the in vitro findings from fibroblast extracts [9] strongly suggest that RNA methylation is unaltered in cystic fibrosis.
A possible explanation for the discrepancy between these results and those of Rennert et al. [13, 14] involves differences in the methods used for measuring the extent of RNA methylation. We have measured the extent of RNA methylation by determining the number of methyl groups per RNA molecule, whereas Rennert and associates have reported measurements on the number of methyl groups per cell without measuring RNA synthesis in those cells. Thus, the observation of the latter group of undermethylated RNA in cystic fibrosis fibroblasts might actually reflect a decrease in total RNA synthesis in these cells. This could be the case if the contact-inhibited, confluent fibroblasts from CF patients, as used by Rennert et al. [14], were growing more slowly than confluent normal fibroblasts. In order to eliminate the variable of differential growth rates, we have utilized exponentially dividing fibroblasts; such cells from CF patients show normal generation times in this laboratory. Another possible explanation for the differences between these findings and those of Rennert and associates relates to transport of $\left({ }^{14} \mathrm{C}\right)$ methionine. If confluent CF fibroblasts had a reduced uptake (or activation) of methionine, RNA might then appear undermethylated in these cells. However, Hodes and Merritt [5] have found in a recent study of confluent fibroblasts that RNA methylation was unaltered in cells from $\mathrm{CF}$ patients.

Although there are minor differences in Rennert's tissue culture medium as compared with ours, it is unlikely that such variables could account for the discrepant rates of RNA methylation. Rather, based on results obtained with cultured cells in other inborn errors of metabolism [10], it is likely that a fundamental chemical defect (as claimed for RNA methylation in 
CF) would be readily and reproducibly identified, despite minor differences in tissue culture techniques.

The analytical methods employed in this investigation were well characterized and established in previous studies of RNA methylation in tissue-cultured cells from various prokaryote and eukaryote organisms [68]. These techniques would readily identify an aberrant RNA methylation pattern. In fact, a strikingly similar pattern of methylation has been observed [8] for eukaryote tRNA, whether isolated from: (1) yeast cells, (2) chick kidney fibroblasts, (3) mouse kidney fibroblasts, (4) CV-1 monkey fibroblasts, or (5) HeLa cells. The results of the present study indicate that tRNA from human skin fibroblasts exhibits the same distribution of these enzymatically controlled, methylated components. Because patterns of RNA methylation are highly specific and preserved throughout a wide variety of disparate organisms, it is improbable that cells from cystic fibrosis patients would show a basic alteration in such an apparently important process. Our comprehensive investigation supports the proposal that methylation of transfer and ribosomal nucleic acid is normal in cystic fibrosis.

\section{Summary}

Methylation of tRNA and rRNA was evaluated in normal human fibroblasts and in fibroblasts from patients with cystic fibrosis. The methylated base and nucleoside composition of $4 \mathrm{~S}, 18 \mathrm{~S}$, and $28 \mathrm{~S}$ RNA species from these cells was found to closely resemble the patterns noted previously for other eukaryote cells. The RNA methylation patterns in the CF fibroblasts were qualitatively and quantitatively similar to those observed in normal fibroblasts. It is concluded that: (1) CF cells are not deficient in RNA methylation, and (2) the latter cannot be employed as a marker for identifying carriers of cystic fibrosis.

\section{References and Notes}

1. Baltimore, D.: Purification and properties of polio virus double-stranded ribonucleic acid. J. Mol. Biol., 18: 421 (1966).

2. Brown, G. M., AND AtTaRdr, G.: Methylation of nucleic acids in HeLa cells. Biochem. Biophys. Res. Commun., 20: 298 (1965).

3. Furano, A. V.: A very rapid method for washing large numbers of precipitates of proteins and nucleic acid. Anal. Biochem., 43: 639 (1971).

4. Hattman, J.: Variation of 6-methylaminopurine content in bacteriophage P22 deoxyribonucleic acid as a function of host specificity. J. Virol., 7: 690 (1971).

5. Hodes, M. E., And Merritt, A. D.: Personal communication.

6. KlagGsBrun, M.: Changes in the methylation of transfer RNA in vaccinia infected HeLa cells. Virology, 44: 153 (1971).

7. Klagsbrun, M.: The contrast between the methylation of transfer ribonucleic acid in vivo and in vitro by normal and SV40 transformed 3T3 cells. J. Biol. Chem., 247: 7443 (1972).

8. Klagsbrun, M.: An cvolutionary study of the methylation of transfer and ribosomal ribonucleic acid in prokaryote and eukaryote organisms. J. Biol. Chem., 248: 2612 (1973).

9. Klagsbrun, M., and Farrell, P. M.: The methylation of ribonucleic acid in fibroblasts of normal volunteers and patients with cystic fibrosis. In: J. A. Mangos and R. C. Talamo: Fundamental Problems of Cystic Fibrosis and Related Diseases (Symposia Specialists, Miami, pp. 53-61 1973).

10. Mellman, W. J., and Cristofalo, V. J.: Human diploid cell cultures: Their usefulness in the study of genetic variations in metabolism. In: G. H. Rothblat and V. J. Cristofalo: Growth, Nutrition and Metabolism of Cells in Culture (Academic Press, New York, 1972).

11. Pallavicini, J. C.: Personal communication.

12. Razin, A., Sedat, J. W., ANd Sinsheimer, R. L.: Structure of the DNA of bacteriophage $\theta$ XI74. J. Mol. Biol., 53: 251 (1970).

13. Rennert, O., Frias, J., Julius, R., and LaPointe, D.: The detection of the heterozygote and homozygote in cystic fibrosis by short term lymphocyte in culture studies: A defect in RNA methylation. Clin. Pediat., 11: 351 (1972).

14. Rennert, O., Julius, R., AND LAPointe, D.: RNA methylation: A possible genetic marker in cystic fibrosis. Pediatrics, 50: 485 (1972).

15. Wagner, E. K., Penman, S., and Ingram, V. M.: Methylation patterns of HeLa cell ribosomal RNA and its nucleolar precursors. J. Mol. Biol., 129: 371 (1967).

16. Wright, S. W., AND Morton, H. E.: Genetic studies on cystic fibrosis in Hawaii. Amer. J. Hum. Genet., 20: 157 (1968).

17. Performed by Microbiological Associates, Bethesda, Md.

18. Schwarz/Mann, Orangeburg, N. Y.

19. New England Nuclear, Boston, Mass.

20. Model 3375, Packard Instrument Company, Downer's Grove, III.

21. Eastman Organic Chemicals, Rochester, N. Y.

22. No. 6065, Eastman Organic Chemicals, Rochester, N. Y.

23. Eastman Kodak Company, Rochester, N. Y.

24. Cyclo Chemical Company, Los Angeles, Calif.

25. The authors are grateful to Dr. Paul A. di Sant'Agnese for his support, encouragement, and helpful comments regarding this manuscript.

26. The present address of Dr. M. Klagsbrun is: Children's Hospital, 300 Longwood Ave., Boston, Mass. 02115 (USA).

27. Requests for reprints should be addressed to: P. M. FArRell, M.D., Ph.D., Pediatric Metabolism Branch, National Institute of Arthritis, Metabolism, and Digestive Diseases, National Institutes of Health, Bldg. 10, Room 8N250, Bethesda, Md. 20014 (USA).

28. Accepted for publication November 1, 1973. 